\title{
ヒトの顎関節の線維構築 FIBRO-ARCHITECTONICS OF HUMAN TEMPOROMANDIBULAR JOINT
}

\author{
井原 邦夫 \\ 群馬大学医学部第二解剖学教室 (主任: 滝沢安子吉教授) \\ 昭和56年 2 月20日 受付
}

\section{I 緒言}

顎関節 (articulatio temporomandibularis) の形態 および構造については種々の動物において，多くの 方法で研究されてきた。特にヒトのそれについては 単行本 (Shapiro, 1954, Sarnat, 1964) および教科書 (Gegenbaur, 1895, Fick, 1904, CunninghamBrasch, 1952, Braus-Elze, 1954, Gardner et al., 1960, Benninghoff, 1961, 上条, 1969, Gray-Warwich, 1973）に詳説されているところである。しかしそ の関節の大部分を構成する線維の組立て方について は, 新しい包埋材の出現にもかかわらず，また七卜

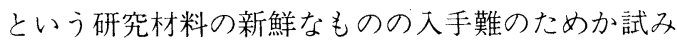
られていない。勿論この研究で実施した膜片標本 (Häutchen-präparat, film-preparation)の方法も試 みられていない. Styrene 包埋のガラス連続切片の 方法および腔器官 (Hohl-organ) の漿膜に対して Vogt（1935）が導入した染色膜片の作製法によって ヒトの顎関節の線維の組立て方に新しい所見を得た ので報告する.

一方, 顎関節の運動については咀嚼筋の個々の筋 電図の所見が，その筋の機能の特徵を明らかにしつ つある。特にヒトの場合媣部に存在するため顎関節 の関節円板 (discus articularis) に停止する外側翼突 筋 (m. pterygoideus lateralis) の運動に関しては論 争中である。

著者のこの構造的な研究の成果は, 七トの顎運動 の解釈に寄与するであろう。

\section{II 研究材料および方法}

使用した顎関節は群馬大学解剖学教室の昭和53年 度, 54年度および55年度の解剖実習用および研究用 (病理解剖後の死体を含む) の死体22体から採取し た。その年齢は39歳より77歳までのものである。材 料は10\% formol 中に保存した。

\section{研究方法}

1） 4 例は側頭骨 (os temporale) および周囲の筋 を付着させたまま $5 \%$ trichlor acetic acid solution にて脱灰後, 融点の高い $\left(56^{\circ} \sim 60^{\circ} \mathrm{C}\right)$ paraffin (histosec, Merck) に包埋し, Reichert-Jung Heavy-duty

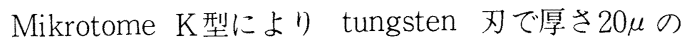
連続切片を作製した。切片は大きいため $50 \times 80 \mathrm{~mm}$ のスライドグラスに貼付した。染色は Hansen's hematoxylin (Chroma) eosin, Weigert's resorcin fuchsin (Chroma), orcein (Merck) にて行なった.

2） 6 例は顎関節円板 (discus articularis) と周囲 の組織とを関節円板中心部から放射状に小部分とし て切り出し, styrene (関東化学) 包埋, PorterBlum microtome を使用してガラスナイフで厚さ 2 一 $3 \mu$ の連続切片を作製した。切断方向は矢状断, 水平断および前頭断である. 脱樹脂は toluene で 行なった。染色は Hansen's hematoxylin eosin, Weigert's resorcin fuchsin, orcein, Heidenhain's hematoxylin にて行なった。

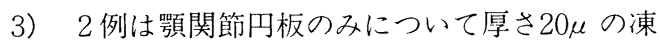
結切片を作製した。染色は Hansen's hematoxylin eosin, Weigert's resorcin fuchsin, orcein, にて行 なった。

4) 膜片標本 (Häutchen-präparat, film-preparation, Vogt, 1935）作製.5例は顎関節円板および 周囲組織を 5〜10区分に切断した。組織片は約 5 $\mathrm{mm}$ の巾に切断して小区分し, block（全塊）染色 (Hansen's hematoxylin 染色後, Weigert's resorcin fuchsin あるいは orcein 染色) を行ない, 実体顕微 鏡下で滑膜（membrana synovialis）を剥がし, glycerin に封入し, 滑膜面から観察した。観察には orcein 染色が適していた。

立体写真（図20、20'，－図28，28）は実体顕微鏡 下での撮影可能範囲が30倍程度（original size）で あるので，この場合には光学顕微鏡下で preparate を左右に傾斜 $\left(5 \sim 6^{\circ}\right)$ して100倍にて撮影した. 
図 1 右側罰関節円板を上から見な图。

reflectionより周辺の attachment が誇張して掋げて亦 る.

图2图4に対方略図(矢状断)。

图1の(2)線およU゙図3の(2)の線における切断图.

图3图 5 亿対守万略図( 前頭断)。

図1の(3)の線㧍よび図2の(3)線における切断図.

园 4 右側顎関節（約2.5倍）の矢状断。 paraffin (histosec) 创埋, Reichert-Jung Heavy-duty Mikrotome K型にて切断.

図 5 右側顎関節（約2.5倍）の前頭断。 paraffin (histosec) 包埋, Reichert-Jung Heavy-duty Mikrotome K型にて切断.
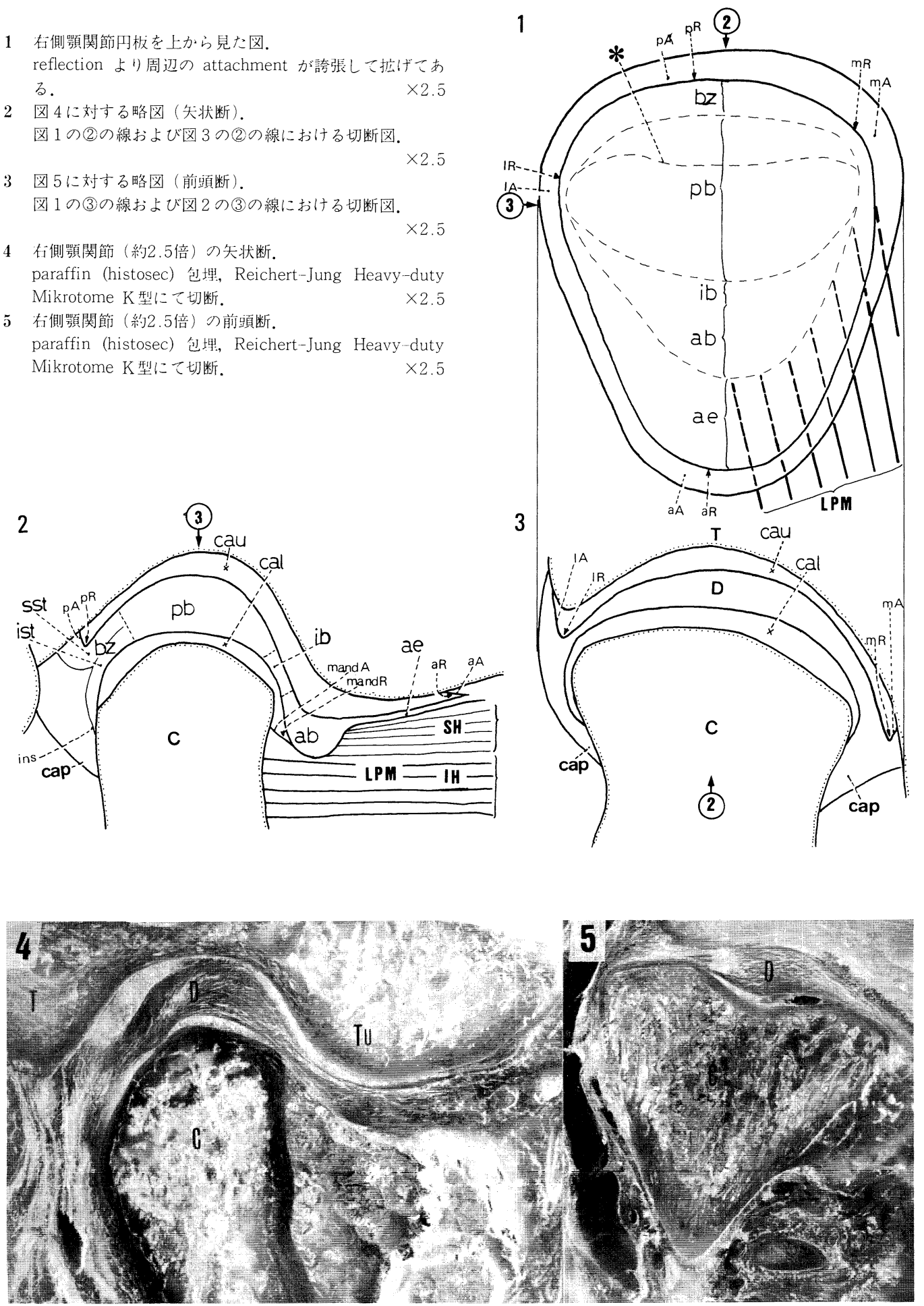


\section{III 観察}

一般的構造については Gray's anatomy の English edition の35版（1973）が数ページを費して Rees（1954）の文献を引用している。顎関節の詳細 を述べる前に，一般的構造を著者は Rees (1954) の 文献を引用しつつ述べる。

顎関節 (articulatio temporomandibularis, P.N.A., B.N.A., : articulus mandibularis, J.N.A.) の特徵的 なことは，側頭骨（os temporale）の下顎窝（fossa mandibularis) 拈よび関節結節（tuberculum articulare) と下顎骨 (mandibula) の関節突起 (processus condylaris, P.N.A., B.N.A., : processus articularis, J.N.A.) の下顎頭 (caput mandibulae, P.N.A., B.N. A., : capitulum mandibulae, J.N.A.) との間に関節 円板 (discus articularis) があることとその関節円板 の前内方に外側翼突筋 (m. pterygoideus lateralis) が停止していることである、関節円板は, 関節結節と 下顎窝と下顎頭との間にある硬い線維組織である。 関節円板全体を見ると, 前つばのある運動帽 (cap) の形をしていて下顎頭を覆っている，上方から見る と, 算円形をなし，その前部のつばの部分は鞍型で, 後部は凸彎している，側方より見ると，下顎頭を水 平にかぶせ，つばを前に向けている，前上方から見 ると, 内外方向では, 前方から後方にかけてわずか に凹彎している，下方より見ると，前部には筋が停 止し，後部では下顎頭の形に一致した凹彎をしてい る. 前頭断すると, 関節円板は内側にやや傾斜して いる(困 $1 \sim 5$ ).

関節円板は横に5つに区分され，それぞれ前から，

1) anterior extension (Rees, 1954 ; pes menisci, Griffin and Sharpe, 1960 ; 前延長部 ; 図 1, 2 の ae, 図 9 ): 関節円板の anterior band の前方で関節結節
の前下方にあり，それを覆っている。その上層は強 靱線維性結合組織で，関節円板のつづきで側頭骨の 関節結節の前縁に終る。その下層の前内側部は外側 翼突筋にあたり，その下層の外側部は血管を含む結 合組織である。

2) anterior band (Rees, 1954 ; hera (?) of pes menisci, Griffin and Sharpe, 1960 ; vorderer Wulst, Lubosch, 1906 ; 前肥厚部；困 1,2の ab)：下顎頭 の前縁に一致して関節円板の横軸に下面より突出す る。その前内側には外側翼突筋が停止する.

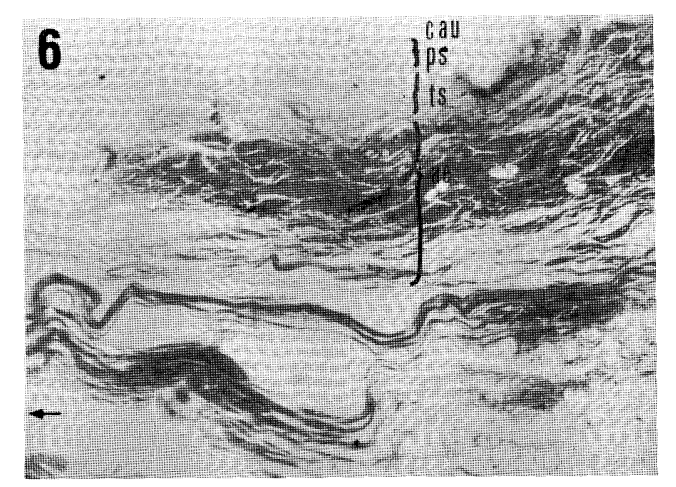

図 6 関節円板の anterior extension (矢状断). (矢印は前方) styrene 切片, H-E, ×60

3) intermediate band (Rees, 1954 ; pars gracilis menisci, Griffin and Sharpe, 1960 ; mittere schmale Zone, Lubosch, 1906 ; 中間帯 ; 困 1, 2 の ib) : anterior band と posterior band との間にあり 薄く狭い部分である。

4) posterior band (Rees, 1954 ; pars posterior menisci, Griffin and Sharpe, 1960 ; hinterer Wulst, Lubosch, 1906 ; 後肥厚部；図 1,2の pb)：下顎頭 の上面は頭部の横軸に向けて横長の槜円形をしてい るその上面に一致して posterior band が存在する.

\footnotetext{
略語表

$\mathbf{a A}$ : anterior attachment $\mathbf{a R}$ : anterior reflection $\mathbf{a b}:$ anterior band $\mathbf{a e}:$ anterior extension $\mathbf{b z}:$ bilaminar zone $\mathbf{C}$ : processus condylaris of mandibula $\mathbf{c h}$ : chondrocytes $\mathbf{c a p}:$ stratum fibrosum of capsule co: collagen fiber $\mathbf{D}$ : discus articularis e : elastic fiber cal : lower space of cavum articulare cau : upper space of cavum articulare $\quad \mathbf{C M}$ : caput mandibulare $\quad \mathbf{F}$ : fossa mandibularis of os temporale $\quad \mathbf{C N}$ : collum mandibulare fp : fovea pterygoidea of processus condylaris $\mathbf{I H}:$ inferior head of $\mathrm{m}$. pterygoideus lateralis $\mathbf{i b}:$ intermediate band ins: insertion ist : inferior stratum of bilaminar zone IA : lateral attachment IR : lateral reflection LPM : musculus pterygoideus lateralis $\mathbf{m A}$ : medial attachment $\mathbf{m R}$ : medial reflection mand $\mathbf{A}:$ mandibular attachment mandR : mandibular reflection $\mathbf{p A}$ : posterior attachment $\mathbf{p R}$ : posterior reflection $\mathbf{p b}:$ posterior band sst : superior stratum of bilaminar zone ps : lamina propria synovialis $\mathbf{s}$ : synovial cells $\mathbf{S H}$ : superior head of m. pterygoideus lateralis $\mathbf{T}:$ os temporalis $\mathbf{t s}:$ tela subsynoviale $\mathbf{T u}:$ tuberculum articulare of os temporale vil : villus synovialis $\quad \mathrm{V}$ : blood vessels * : posterior ridge of caput mandibulare
} 
5) bilaminar zone (Rees, 1954 ; 二層部; 図 1 , $2, の \mathbf{b z}$, 図 7 ) : superior stratum(上層)と inferior stratum (下層) との二層に分かれる. superior stratum は posterior band の後縁より posterior temporal attachment（後述）までの間の部分をいい， inferior stratum は posterior band 後縁より下顎頸 (collum mandibulare) に付着するまでの部分をい

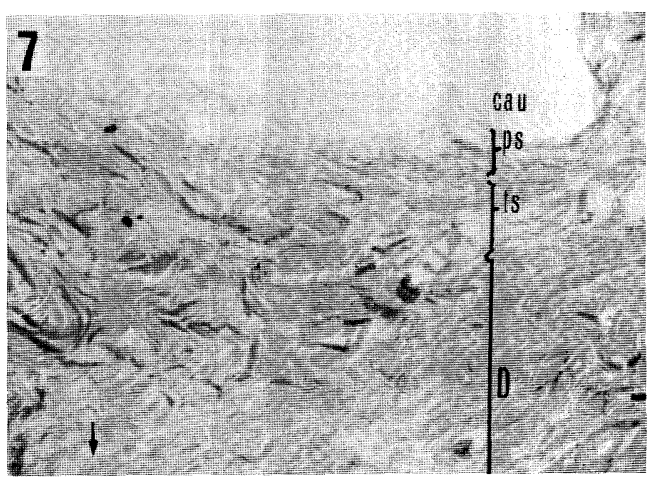

図 7 関節円板の bilaminar zone $の$ superior stratum (矢状断). styrene 切 $\mathrm{H}_{\mathrm{i}}, \mathrm{H}-\mathrm{E}, \times 60$

う.関節円板の厚さは均一ではなく,2),4)部で厚く, 3) 部で薄い。関節円板は計測すると，上面では縦の 長さが約 $15 \mathrm{~mm}$ であり，下面では約 $10 \mathrm{~mm}$ である。 横の長さは上下両面とも約 $10 \mathrm{~mm}$ である。関節円板 の(1) anterior extension, (2) anterior band, (3) intermediate band, (4) posterior band, (5) bilaminar zone の長さは, 各々約(1) $4 \mathrm{~mm}$, (2) $2 \mathrm{~mm}$, (3) $2 \mathrm{~mm}$, (4) $3 \mathrm{~mm}$, (5) $4 \mathrm{~mm}$ で, 各々の厚さは最も 厚いところで(1) $2 \sim 3 \mathrm{~mm}$, (2) $2 \sim 3 \mathrm{~mm}$, (3) $1 \sim 2$ mm, (4) $2 \sim 3 \mathrm{~mm},(5) 3 \sim 4 \mathrm{~mm}$ であり, 最も薄い 所は(3)である.

各々の骨と関節円板との間に attachment (付着 部）が存在し (Rees, 1954), attachment が存在す るところには reflection（折れ返り）がある.Attachment はこの reflection から各々の骨へ移行す る部分をいう。この部分は後述するが，付着部とい うよりは，運動のための一種の余裕部 (reserve region）ということができる. attachment は場所に よって次のよjに名づけられるが図1では強調して 拡げてある。(1) anterior temporal attachment（前 方一側頭骨付着部，図 1，2の aA）：関節円板の anterior extension の前縁の reflection から側頭骨 までの間の部分. (2) posterior temporal attachment（後方一側頭骨付着部, 図 1,2 のA）：関節
円板の bilaminar zone の superior stratum (図 2 の sst) の reflection から側頭骨までの部分. (3) medial temporal attachment (内側-側頭骨付着部, 図 1，3の $\mathbf{m A}$ ) : 関節円板の内側の周辺部の reflection から側頭骨までの間の部分. (4) lateral temporal attachment (外側-側頭骨付着部, 図 1,3 の 1A）：関節円板の外側の周辺部の reflection か ら側頭骨までの間の部分. (5) anterior mandibular attachment（前方一下顎骨付着部，図 20 mand A, 図14）：関節円板の anterior band の下縁から下顎 頸の前縁までの間の部分。

ここで注目すべきは，関節円板の下後方部では， 関節円板から下顎頸の後縁までの間に reflection は なく bilaminar zone の inferior stratum（図2の ist）からの線維は下顎頸の後上部に下顎頭の円弧の 接線方向に付着する。ここでは posterior mandibular attachment (Rees) の名称を保留してこの部分を insertion（停止部，図 $2 の$ ins，図15）とする。

関節円板から側頭骨の attachment までの間およ び関節円板から下顎頸の前縁までの間の大きく折れ 曲った部分を reflection（折㣗返り）という（前述， Rees, 1954). Reflection は場所によって次のように 名づけられる. (1) Anterior temporal reflection,

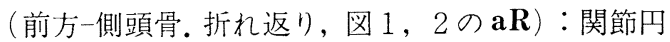
板の anterior extension $と$ anterior temporal attachment との間で大きく折れ曲った部分. (2) Posterior temporal reflection (後方一側頭骨. 折れ返 り，図 1，2の pR) : bilaminar zone $の$ superior stratum と posterior temporal attachment との間 で大きく折れ曲った部分。(3) Medial temporal reflection (内側一側頭骨. 折れ返り, 図 1,3の $\mathbf{m R}$ ) : 関節円板の内側の周辺部と medial temporal attachment との間で大きく折れ曲った部分. (4) Lateral temporal reflection (外側-側頭骨. 折れ返り, 図 1, $3 の \mathbf{I R})$ : 関節円板の外側の周辺部と lateral temporal attachment との間で大きく折れ曲った部分. (5) Anterior mandibular reflection（前方一下顎骨. 折れ返り，図 $2 の$ mand $\mathbf{R}$ ): 関節円板の anterior band の下縁と anterior mandibular attachment との間で大きく折れ曲った部分である。これらの reflection は lamina propria synovialis (滑膜固有 層), tela subsynovialis (滑膜下組織) の特に厚い所 で, plica synovialis(滑膜七ダ)が良く発達している. 関節円板には外側翼突筋 (m. pterygoideus later- 
alis)の上頭が停止する。外側翼突筋は二頭筋であり， 上頭は側頭下窝 (fossa infratemporalis) の蝶形骨大 翼 (ala major ossis sphenoidaris) の後縁より, 下頭 は蝶形骨翼状突起外側板 (lamina lateralis processus pterygoidei）外面より起始する。上頭は関節円板の anterior bandの前縁より内側縁にわたって停止し， 下頭は関節突起の下䫈頭の前内面の翼突筋窩 (fovea pterygoidea）に停止する. 以上を考慮して図 2 は顎 関節の中心部を通って矢状断したものであり, 図 3 は前頭断したものである。図 1 は関節円板を上から 見たものである.四 4, 5 は図 2,3 の部分を paraffin (histosec) で包埋し, tangusten 刃で切ったものであ るが, 薄切すると局所的な関係がくずれてしまうの で切断面を示した。

顎関節の滑膜 (membrana synovialis)については, ほとんど記載されていないが詳細は後述する。関節 包 (capsula articularis, 図 2, 3 の cap) は外層の stratum fibrosum（線維層）と内層の stratum synoviale (滑膜層) とに分けられる. stratum synoviale は関節軟骨 (cartilago articularis) を除いた関節腔 (cavum articulare) を裏打ちする.

脈管, 神経は関節円板の周辺部および attachment に認められる。また顎関節の retroarticular region には脈管, 神経を含む脂肪組織のあることを Zenker (1956)は retroarticuläre plastische Polster として記 載し，それに機能的な意義をもたせている。

切片標本： 関節円板 (discus articularis) は主に 厚い線維軟骨から成っている。この軟骨部とそれ以 外の部分には太い膠原線維束が走っている。関節円 板の膠原線維束の走行については, Lubosch (1906), Rees (1954), Griffin and Sharpe (1960, '62), Dixon (1962), Thilander (1964), Sicher (1966), 布施(1980), 神宮司ら (1980)，が記載している。彼らは関節円板 を前方, 中央, 後方に区分し，それぞれの部分にお ける線維は, 前方および中央部の薄い所ではお互い に平行であり, 後方部では前後, 横断, 垂直方向一 交織している。その関節円板は膠原線維が緻密に組 込まれたものである。また Rees, Thilander および Sicher は関節円板は構造上から見て外側翼突筋の 線維部分，即ち腱であろうとしている。

切片所見によると線維軟骨部以外においては線維 束の方向ははっきりし，軟骨部においてもある程度 決定できる。即ち関節円板全体において太い線維束 は放射状に，細い線維束は同心円状に走行している
が，関節円板中心部においてはこれらの方の他に 垂直に走行する線維束も存在し，これらの束が互い に不規則に交錯している（図 8，9）。関節円板中心

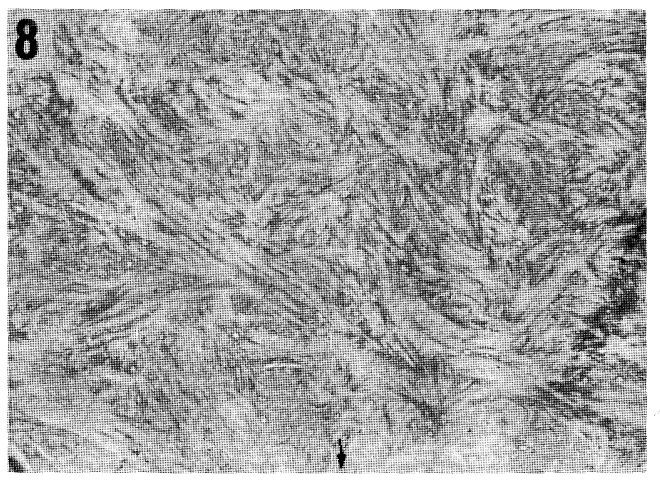

図 8 関節円板の中心部 (水平断). (矢印は前方) styrene 切牌, $\mathrm{H}-\mathrm{E}, \times 50$

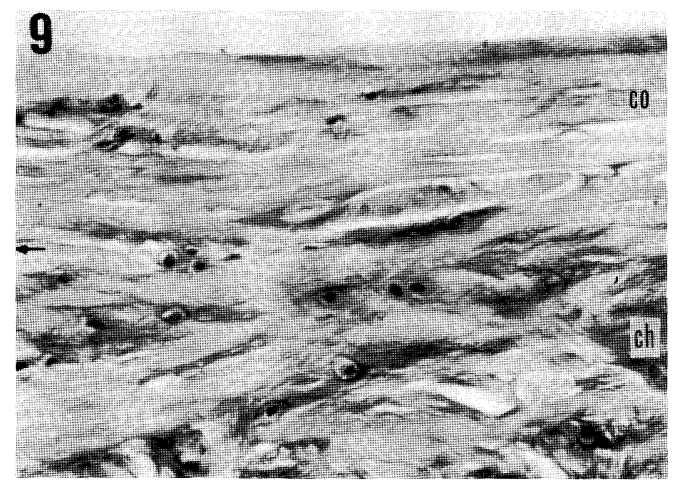

図 9 関節円板の中心部 (矢状断)。(矢印は前方) 凍 結切片, $\mathrm{H}-\mathrm{E}, \times 170$

部 (anterior band, intermediate band, posterior band）では，中心が前と後とに分かれたような形， 即ち棈円中心が前後に分かれたような形をしてい る. 前の中心が anterior band にあり，後の中心が posterior bandにあり，それらの中間が intermediate band である. 即ち関節円板中心部の線維束は それぞれの中心から放射状に走行するものが主であ り，それぞれの中心に対して同心円状に走行するも のもあるが intermediate bandにおいては線維束は 前後方向に走行する。関節円板の周辺部においては, anterior extension では線維束は前後方向に，即ち 関節円板中心部に対して放射状に走行する。また後 方の bilaminar zone においては線維束は前後方向, 即ち関節円板中心部から放射状に走行する。 bilaminar zone の superior stratumでは前後方向に走 
る線維束がさらに延長して関節円板から上方に反転 して, posterior temporal attachment となり側頭 骨の関節简後縁に付着寸る。一方，inferior stratum においては，前後方向に走る線維束は下顎頸の後縁 の接線方向に付着する。関節円板周辺部の内側部に おいては，関節円板中心部から放射状に走行する太 い線維束が主で，これに同心円状に走行する細い線 維束が加わる.また内側の周辺部の内側, 即ち medial temporal attachment においては, 線維束は側頭骨 に向って反転して付着する。内側部の前方には太い い線維束が関節円板中心部から放射状，即ち外側翼 突筋の力向に走行する (図13). 関節円板の周辺部の 外側部では，関節円板中心部から放射状に走行吉る 線維束の一部は上方に反転して lateral temporal attachment となり側頭骨に付着する（図11，12）（神 宮司ら，1980，による)。

関節円板の線維軟骨の分布： 関節円板の矢状断 および前頭断による連続切片にて線維軟骨細胞の存 在および分布範囲を観察した（図10). 矢状断におい て線維軟骨細胞は関節円板中心部（anterior band, intermediate band, posterior band) に存在する。ま た bilaminar zone の superior stratum では線維軟 骨細胞は，その前方 $1 / 3 の$ 範囲に分布し，その直接下 層の inferior stratum では線維軟骨細胞はほとんど ない，前頭断において線維軟骨細胞は関節円板中心 部に存在するが，その範囲はやや内側寄りである。

\section{0}

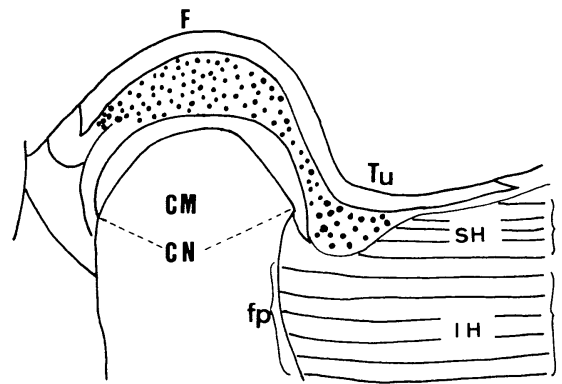

図10 線維軟骨細胞の分布図. 左困は，右側顎関節の久状断．右図は，右側顎関節门板を上から見た図． $\times 1.5$

性線維が多く，それの外側部においては弾性線維が 少ない.この所見は機能的な意味があると思われる。 ヒトの関節円板に扔ける線維軟骨細胞の存在につい ては, 有については〔Peterson (1930), Schaffer (1930), Baecker (1931), Rees (1954), Griffin and Sharpe (1960), Dixon (1962), Sicher (1966)] と, 無に ついては〔Lubosch (1906), Thilander (1964), 鈴木 (1971)」が記載しているが, これらの研究者らの差 は，材料の年齢差によると思われる。

滑膜 (membrana synovialis) の組織学的構造につ いては Hammer (1882), Davis (1945), Caster (1960), Barland et al. (1962), MacConail (1973) が記載し ているが, Nomina histologica (1970, '75, '77)による と stratum synoviale (滑膜層)は, lamina propria synovialis（滑膜固有層）と cellula synovialis（滑膜 細胞）とから成るが, 表面の凹凸の状態により pars villosa (䋐毛部) と pars planna (平滑部) とに区別 される。即ち plica synovialis（滑膜七ダ）およびそ の変形したものと考えられる villus synovialis（滑膜 絨毛）を表面に備えている部分が pars villosa であ り，これを持たない部分が pars planna である。 Nomina histologica では tela subsynovialis は採用 していないが, Bloom and Fawcett (1976) はこれを 使用している。顎関節における lamina propria synovialisより下層に, 著者は tela subsynovialis を認 める。滑膜について Key-Cowdry （1932）は，(1)

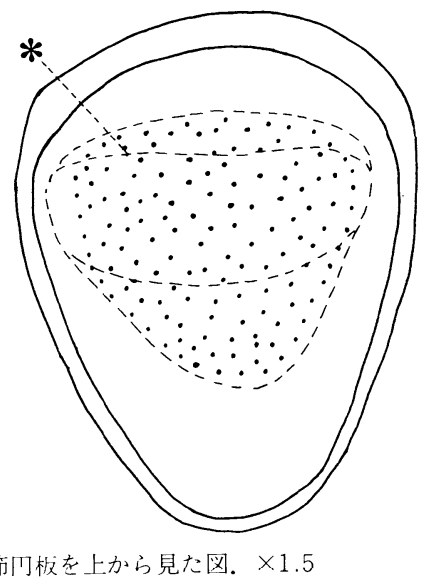

線維軟骨細胞の分布とその周辺部の弾性線維の分 布との関係については詳細は後述するが, 線維軟骨 細胞のない関節円板周辺部には弾性線維が存在す る。そして関節円板の周辺部の内側部においては弾 areolar type, (2) fibrous type, (3) adipose type に分 類し、これらの間には移行があるとした. Bloom and Fawcett (1976) は Key-Cowdry (1932) の分類を継 承して, (1) loose connective type, (2) dense con- 
nective type, (3) adipose type とした。この用語 は tela subsynovialis の中に含まれる組織を考慮し たものと思われる。

Stratum synoviale は関節円板周辺部で厚く, 関節 円板中心部に向って薄くなる。関節円板の矢状断, 前頭断切片に扔ける stratum synoviale の厚さは, 関節円板の線維軟骨の分布と関連している，即ち stratum synoviale の厚さは線維軟骨の存在する部 分（四10）では薄く, 線維軟骨を欠く部分で厚い。 この stratum synoviale の特に厚い部分は側頭骨と 関節円板との間の reflection, および anterior mandibular reflection であり, その厚さは他の部と比べ ると約 5 倍であり最も厚い所では0.4 0.5mm で ある(図11〜15). Cellula synovialis は関節円板中心 部では碉平であり，関節円板周辺部では立方状にな る.即ち stratum synoviale の薄い部分(関節円板中 心部)では扁平であり, stratum synoviale の厚い部 分 (関節円板周辺部) では立方状になる (図15, 16). Lamina propria synovialis は関節腔に面している stratum synoviale の表層にあり，前述の cellula synovialis がこの表面に分布している. lamina propria synovialis の厚さは関節円板中心部から関節円 板周辺部に向って厚くなる。これは stratum synoviale の厚さの変化と一致している. 前方では anterior extension から reflection に移行するに従っ て厚くなる。下前方では anterior mandibular attachment で厚くなる.内側, 外側では, 関節円板中 心部から周辺部に移行するに従って厚くなる。関節 円板中心部の線維軟骨の存在部では薄くそれと一体 となって関節円板の表面を覆っている（図13，15）. Tela subsynovialis は lamina propria synovialis $の$ 直下に存在し, lamina propria synovialis と同様に関 節门板周辺部で厚くなり, reflection で最も厚く，そ れは疎性結合組織から成る(図11，12，13，16). plica synovialis は関節腔の内部に膜状に張り出したもの で，関節円板周辺部の reflection 付近で発達してい る.この plica は前方の anterior extension の reflection 付近, 後方の bilaminar zone $の$ superior stratum から reflection 付近, 下前方の anterior mandibular attachment $の$ reflection 付近, および 内側と外側の reflection 付近でよく発達する. Plica synovialis には所々に長い villus synovialis があ る(図15, 16).

Stratum synoviale の脈管は, 関節円板周辺部の

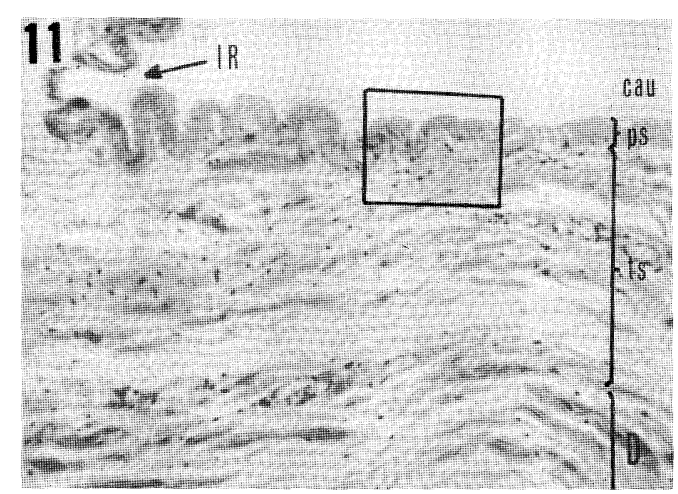

図11 関節円板の外側の周辺部 (矢状断). styrene 切 $\mu_{5}, \mathrm{H}-\mathrm{E}, \times 90$

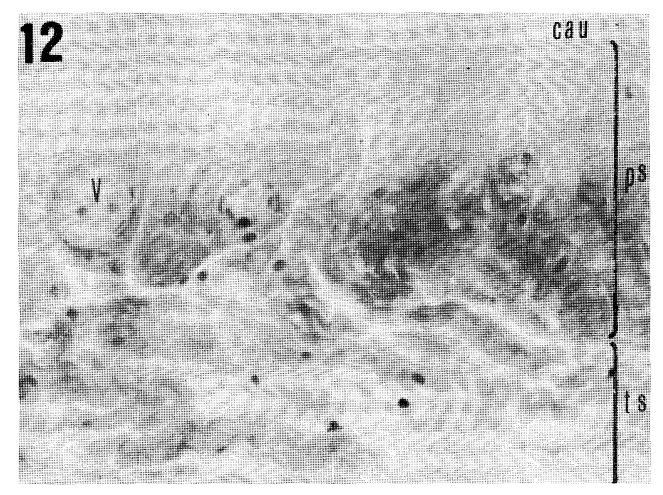

図12图11の搪大図. styrene 切片, H-E, × 310

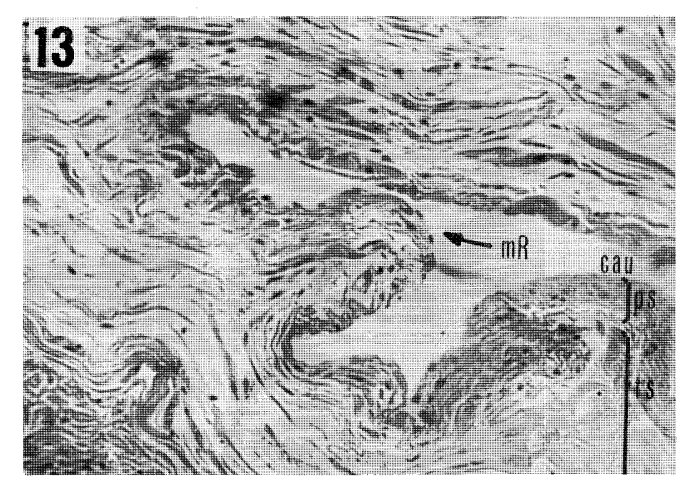

図13 関節円板の内側の周辺部 (矢状断). styrene 切 片, $\mathrm{H}-\mathrm{E}, \times 140$

reflection に多い。線維軟骨の存在する部分では脈 管の存在はほとんど認められないが，それは関節円 板周辺部の lamina propria synovialis および tela subsynovialis の中に認められる.

弾性線維の顎関節における存在について Rees 


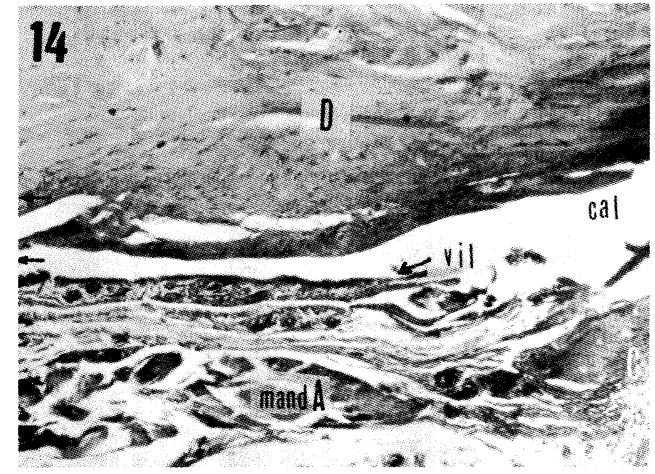

図14 関節円板の anterior mandibular attachment（矢 状断). (知印は前方) paraffin 切片, $\mathrm{H}-\mathrm{E}, \times 60$

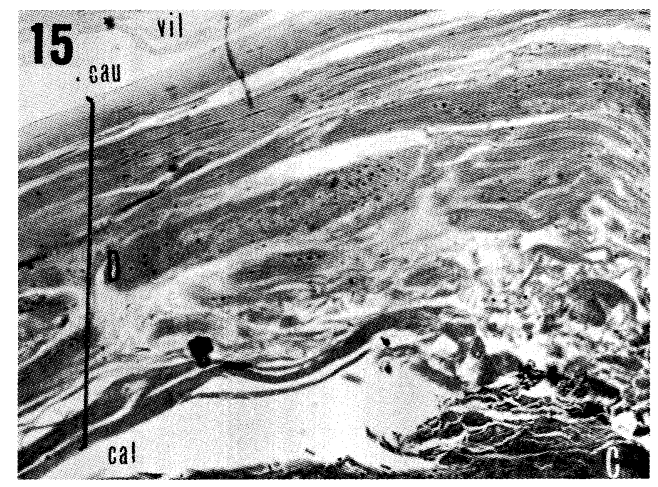

図15関節円板の下顎頸への付着 (矢状断). styrene 切 $H_{i}, \mathrm{H}-\mathrm{E}, \times 60$

(1954), Frommer et al. (1956), Griffin and Sharpe (1960, '62), Dixon (1962), Thilander (1964), 鈴木 (1971）は関節円板の bilaminar zone の superior stratumに多くその inferior stratum には弾性線維 が少ないと記載している。 Thilander（1964）によれ

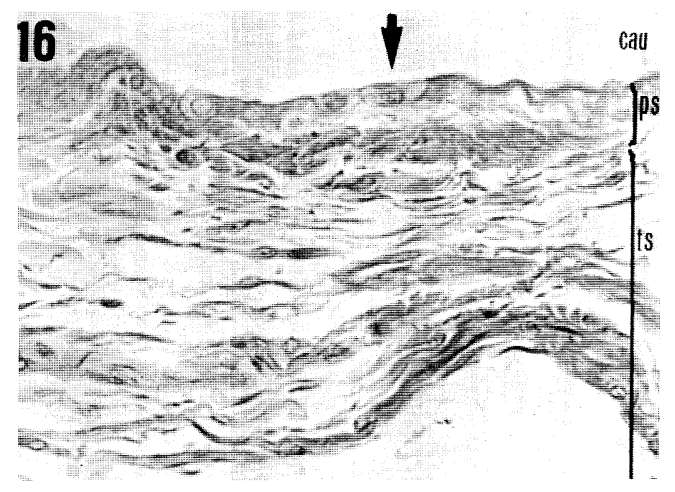

図16 関節円板の内側の周辺部 (矢状断). styrene 切片, orcein, $\times 310$
ば，関節円板の弾性線維の走行は胎児においては膠 原線維の走行と同様であるが，この弾性線維は成人 においては認められないという。著者の切片所見に おいては，関節円板中心部では弾性線維はほとんど ない，関節円板周辺部においては弾性線維の分布に は各部により差異がある。Anterior extensionにお いては弾性線維は全体にわたり多い。後方部におい ては bilaminar zone $の$ superior stratum から posterior temporal attachment までの範囲で弾性線維 は多いが, bilaminar zone の inferior stratum では 弾性線維が少ない。関節円板の内側の周辺部におい ては，外側翼突筋停止部から medial temporal attachmentにかけて弾性線維が多い. Anterior-mandibular attachment および関節円板の外側の周辺 部では弾性線維が少ない。切片においては弾性線維 は膠原線維束の間に細く短かいカール状の線維とし て認められる(図16).

膜片標本： 関節を小部分に分けて block (全塊) 染色をして目的物を膜様に剝がして検鏡する方法で ある。この方法は腹膜について，Vogt (1935), Pfeiffer (1938), Bentenrieder (1939), 滝沢(1949, '50) が応用している。この標本においては，切片標本で は期待できない所見を得ることができる，例えば図 16は関節円板内側の周辺部の切片であるが，この膜 片は図17のように見える(図16，17）。これで明らか なことは，弱拡大では七ダが見える。次に強拡大で は表面から cellula synovialis と lamina propria synovialis の線維と tela subsynovialis の線維が観 察される。また弾性線維染色では, 弾性線維が網目 状に見えることである。

関節の滑膜の膜片標本において，まず初めに

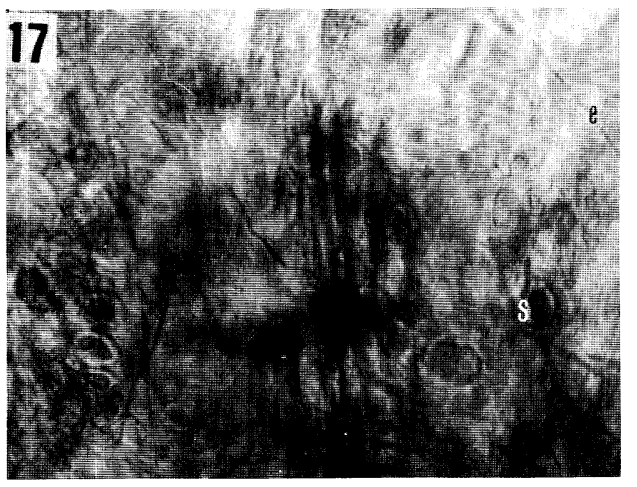

図17図16を上方（太い矢印の方向）から見た膜片標 本. 膜片, orcein, $\times 310$ 
hematoxylin で淡く染め, その後弾性線維染色 (Weigert's resorcin fuchsin または orcein) を行 なった。弾性線維染色には orcein の方が適してい た。 Orcein においては膠原線維を共染するが弱いた め, 弾性線維との区別がよりはっきりするためであ る.

小部分に切った膜片標本の所見を再構成すると, stratum synoviale における lamina propria synovialis の関節円板中心部，即ち線維軟骨の存在する ところでは膠原線維の走行は不規則であるが(図26, $\left.26^{\prime}\right)$, 関節円板周辺部においては翏原線維は関節円 板中心部に対して同心円状に走行する（四20.20， 21. 21', 22. 22', 24. 24', 25. 25, 27. 27', 28.
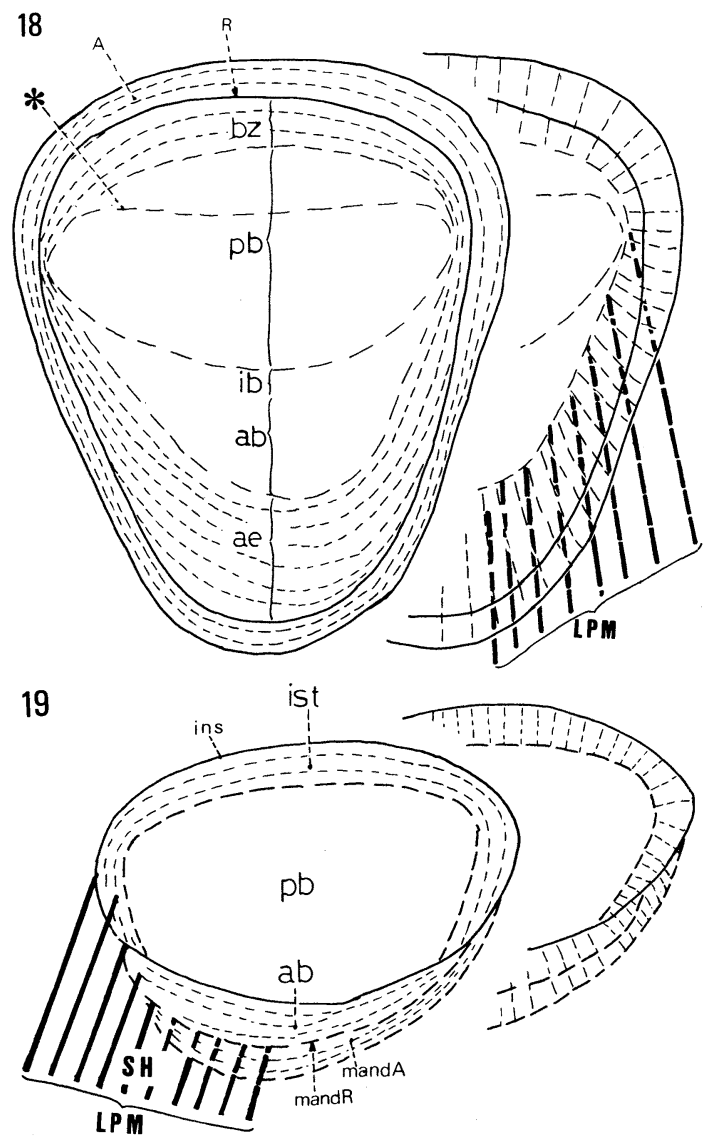

図18 右側顎関節円板を上から見た模式図.

図19 右側顎関節円板を下から見た模式図. 左図は lamina propria synovialis の膠原線維の走 行.右図は tela subsynovialis の膠原線維の走行. 膜片標本による、attachment は誇張して拡げてあ 3. $\times 2.0$
28'). tela subsynovialis は関節円板中心部では存在 しない（前述）が，関節円板周辺部においては疎性 結合組織からなり，周辺部に行くに従って厚くなる. そして膠原線維が関節円板中心部から放射状に走行 する(図18,19).上述の如く stratum synovialeにお ける翏原線維の走行は lamina propria synovialis と tela subsynovialis とでは異なる. Cellula synovialis は関節円板中心部では扁平であり（図26.26”), 関節 円板周辺部では立方状である(図24.24').

Stratum synoviale における弾性線維の走行は, 膠 原線維とは異なり, lamina propria synovialis と tela subsynovialis とがはっきり区別できない.弾性線維 は関節円板中心部においては，切片ではほとんど見 られないが, 膜片では関節円板中心部に対して同心 円状に走行するものがわずかに存在する。線維軟骨 の存在しない関節円板周辺部では, 弾性線維の走行 は膠原線維束 $(15 \sim 20 \mu)$ と同じで, 関節円板中心部 に対して同心円状に走行するが，局所においては異 なった走行をする。即ち弾性線維 $(1 \sim 5 \mu)$ は an terior extension (図20,20'), bilaminar zone の superior stratum (図21.21'), および関節円板の内 側部の外側翼突筋停止部付近（図23.23'）では, 関 節円板中心部に対して同心円状に走行するものが主 であるが，放射状にも走行する。この部の弾性線維 は不規則な網目状構造をなしているが（図20.20，

21. 21'，23. 23’), 血管の弾性線維とは異なり, 一層 の網目ではなく多層の網目状構造をしている，有空 膜は形成していない. Anterior extension の内側か ら内側部における外側翼突筋停止部の上層の弾性線 維の走行は, 膠原線維の走行に一致して関節円板中 心部に対して同心円状に，下層は関節円板中心部か ら放射状に走行し, 立体的網目状構造をする（図20。 $\left.20^{\prime}\right)$. 関節円板全体としては, 弾性線維の走行は膠原 線維の走行とは全部は一致していない。切片所見で は弾性線維は関節円板外側部より内側部の方が多い が，これは膜片所見でも一致する（図24.24，25. $25,27.27$ ，28，28'). 膜片の弹性線維染色におい ては，各部の弾性線維の多寡が一層はっきりする。 即ち弾性線維の特徵的所見は, (1) 弾性線維の太さ は 1 〜 $5 \mu$ であり，(2) 一本の太い線維が所々に小 枝のような側枝を出している。そして，(3) 切片で は細く短いカール毛状の線維として認如れるが, 膜片では一本の一定の方向をもった長い線維として 観察される。 
Plica synovialis は関節円板周辺部に移行するに

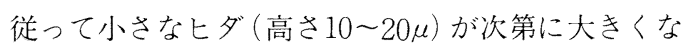
る。大きな七ダの表面にはまた小さなヒダが存在す る. lamina propria synovialis の膠原線維の走行は, この plica synovialis の走行に一致する. Plica synovialis は reflection 周囲で最も発達していて, 大き なヒ多なっている（図11，12，13）。

\section{IV 考察}

顎関節 (articulatio temporomandibularis) の運動 については open(開口), close(閉口), protrusion(前 方), retrusion (後方), lateral (側方) 運動がある〔参 照：Rees (1954), 黑江 (1956)（ヒトの死体におい て), Findlay (1963), Klineberg et al. (1970), Basmajian (1974)（ヒトの生体において), Grant

(1973-A), Carlson et al. (1978)（サルにおいて), MacConail (1966)（ヒトの関節について）記載して いるが, Fick（1904）にはその運動についての記載 はない了.

この中で特に問題となるのは, open（開口), close (閉口) 運動である. 㖽運動の問題については, (1) 死体における筋を局所的に研究し, 顎運動を再 構成したもの，(2) 当該の筋の電気刺激，（3）皮膚 を通して筋の活動を視診, 触診したもの，(4) 咀嚼 筋麻焯患者の研究からの推測があった Basmajian-

(1974). また，(5) X 線写真像から下顎の運動が解 明されてきたRicketts (1954).ささらに顎関節造影法 による上下関節腔の運動との関係が $X$ 線写真上で論 じられた (Norgaard, 1944, 高久, 1980).

一方筋電図による分析が行なわれ顎運動と外側翼 突筋との関係が論じられた. Moyers (1950), Carlsöö (1956), Basmajian (1974) は, 筋電図において 外側翼突筋の運動を分析し, 外側翼突筋は開口時の みに㗢く単一機能を有するだろうと記載している。 しかし, Zenker and Zenker (1955, ’56)は開口時の みならず閉口時にも外側翼突筋は筋電困において, はっきりした衝撃を観察している。さらに Grant (1973-A), McNamara (1973)はサル (Macaca mulatta）を用いた筋電困の実験で，外側翼突筋の上 頭 (spheno-meniscus head) と卜頙とは各々独立し た働きをしていることを記載し, 上頭の筋電図の活 動は特別な閉口時 (chewing, swallowing, 歯の clenching）に観察した。下頭は，開口時に下顎が下 方, 前方, 側方に移動するのを助けるが, 上頭は恐
らく下顎と関節円板とを関節結節に対して安定させ る (meniscus stabilizer) と推測した。また Grant (1973-B ) は，顎運動について下顎の機能的な回転 が center of condyle (関節突起の中心の固定軸) (Rees, 1954, Braus, 1954, Shapiro, 1954, Sarnat, 1964）で行なわれるのではなくて, instantaneous center of rotation(瞬間的中心軸)で行なわれると記 載し, さらにヒトの下顎の運動を行なう筋が, サル の場合と同様に㗢くと述べている. McNamara （1973）は顎運動を see-saw 運動に相似させ，その 支点は上述の instantaneous cneter of rotation で この see-saw 運動の微妙な上下のバランスをとる 動作者が上頭であるとした。

かくの如き顎運動と線維構築との間には, 力学機 能的 (mechanisch-funktionell) 関係が存在すると著 者は考える。線維構築が力学機能的な存在であるこ とは，すでに古くTriepel (1908), Benninghoff ( 1961)らによって明らかにされているところである。 （1）上下関節腔に封して lamina propria synovialis は cellula synovialis の支持台になるものであり，(2) tela subsynovialis は lamina propria synovialis と関 節円板とに対するずれを緩衝するものであろう。(3) 関節円板は外側翼突筋の延長であり，かつまた線維 軟骨の存在する部分は, pad としての役割をするも のであろう。(4) Attachment の存在及び plica synovialis の存在は，その下敷である関節円板および 関節包 (capsula articularis) の stratum fibrosum に対するずれを緩衝する役割と, 脈管, 神経組織に 対する場所を提供するものであろう。この様な線維 構築の存在は次のような関節円板の運動を含めた関 節の運動を推測させる.

まず open（開口）運動における下顎頭の前方への 移動に際して bilaminar zone の inferior stratum は 下顎頭と一体となって，お互いにずれないで前方に 移動するであろう。その際 anterior band から下顎 頸前緣に付着する anterior mandibular attachment は下顎頭の前方移動に伴ない anterior mandibular reflectionはなくなり,逆に anterior extensionにお いては，その前縁が anterior temporal reflectionに とり込まれつつ anterior temporal reflection は前

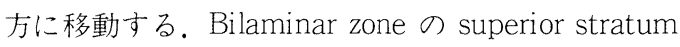
においては, posterior temporal attachment $の$ superior stratumにとり込まれ posterior temporal reflectionは極端には posterior temporal attachment 
の側頭骨への付着まで移動する。Close（閉口）運動 においては open（開口）運動の逆の作用が働く. Bilaminar zone の inferior stratum は, 下顎頭と一 体となってそのまま後方へ移動するが, anterior mandibular attachment は弛緩し, anterior mandibular reflection をつくりもとの状態にもどる. Open（開口), close（閉口）運動の矢状面における その運動に際して, lamina propria synovialis の plica というよりは Rugae が伸ばされ tela subsynovialis とその下敷の関節包の stratum fibrosum や 関節円板との間のずれに対して tela subsynovialis の線維が走る。また関節円板がもとにもどる時，外 側翼突筋の上頭が働き関節门板がずれ込むのを防い でいると推測される。

Lateral（側方）運動においては，下顎を右側に動 か寸時，左側が受動的な運動となり，逆に下顎を左 側に動かす時、右側が受動的な運動となる。この時 lateral および medial attachment が緩衝するであろ j.

関節円板において外側部と内側部とでは, 弾性線 維の走行および量に差異がある。即ち lateral temporal attachment に比較すると medial temporal attachment では弾性線維が多いこと,それらの走行 は，全体的に関節円板中心部に対して同心円状であ るが, 内側部の外側翼突筋停止部周辺では立体的網 目状構造であること。この所見は関節円板の外側部 の attachment が内側部の attachment に比べてよ り受動的になるということであろう。逆に関節円板 の内側部の attachment に弾性線維が多いというこ とは，この部では外側翼突筋による機械的な力の関 与および，関節円板をもとにもどそうとする積極的 な働きがあり，外側部では積極的な作用がないであ ろうと考えられる。また anterior extension および anterior temporal attachment $と$, bilaminar zone $の$ superior stratum および posterior temporal attachment とにおける各々の部分では, 関節円板周辺部 の内側部および medial temporal attachment と同 様の弾性線維の立体的網目状構造が存在するが, こ れらは open（開口), close（閉口）運動および lateral (側方) 運動に対して plica synovialis が伸ば された状態および縮められた状態をもとにもどそ うとする積極的な働きをすると推測される。

関節円板の後部の下顎頸への付着部が, Rees (1954）のいj attachmentではなく,むしろ関節円
板，および関節円板の bilaminar zone の inferior stratum を介しての外側翼突筋の上頭の insertion と思われる所見は, Grant (1973-A), MicNamara （1973）の頙運動に対する推測を支持するものであ る.

$$
\mathrm{V} \text { 総括 }
$$

1. ヒトの顎関節 (articulatio temporomandibularis）の各部の線維構成を明らかにする目的で, 次の三つの方法を用いて研究した。(a) Histosec (Merck) にて関節全体を包埋, Reichert-Jung Heavy-duty Mikrotome K型により tungsten 刃で 切片を作製し染色した。(b) 関節の小部分を切断し styrene にて包埋，必要な方向にガラスナイフで切 片を作製し染色した。また，(c) Block（全塊）染色 した後, 滑膜 (membrana synovialis) の膜片標本 (Häutchen-präparat， film-preparation) を作製し た。

2. 切片標本による顎関節の関節円板 (discus articularis) および滑膜の場所による線維構成の特徵 が記載された。(a) 典型的には stratum synoviale は, cellula synovialis と lamina propria synovialis と tela subsynovialis とからなるが, 䫈関節の関節円 板中心部では, lamina propria synovialis $と$ tela subsynovialis とが関節円板の線維と一緒になる。関 節円板周辺部と周辺部の関節軟骨 (cartilago articularis）に移行する部分（attachment, Rees, 1954）と では, 三者が存在し, lamina propria synovialis と tela subsynovialis とが区別し得るように厚くなる。 特に reflection (Rees, 1954) では最も原くなる。(b) Cellula synovialis は関節円板の線維軟骨の存在寸る 部分, 即ち関節円板中心部では極端に扁平になり， 関節円板周辺部の線維軟骨の存在しない部分では立 方状になる。

3. 膜片標本による滑膜線維の走行を記載した。 (a) Lamina propria synovialis の膠原線維は, 関節 円板中心部に対して同心円状に走行する。(b) Tela subsynovialis の膠原線維は, 関節円板中心部から放 射状に走行する。(c) 弾性線維は関節円板中心部に 対して全体的に同心円状に走行するが，anterior extension, bilaminar zone, 関節円板の内側の外側翼突 筋 (m. pterygoideus lateralis) 停止部周辺において は立体的網目状構造が存在する。

4. 滑膜の上記の構造は, 線維構築の力学機能的 
(mechanisch-funktionell) な存在で, 関節円板の運 動を含めた顎関節の運動を推測させる。

稿を終るにあたり，終始ご指導とご校閲を賜わった恩師滝 沢安子吉教授に心より謝意を表するとともに，ご協力いただ いた神宮司洋一博士および教室員各位に深謝いたします。 本論文の一部は1980年 4 月, 第85回日本解剖学会総会 (於, 福島）において発表した。

\section{立体写真}

膜片標本, orcein，倾斜角度 $(5 \sim 6)$, 写真の上方が posterior part, 右側が medial part に統一してある。(矢印は 前方) $\times 240$
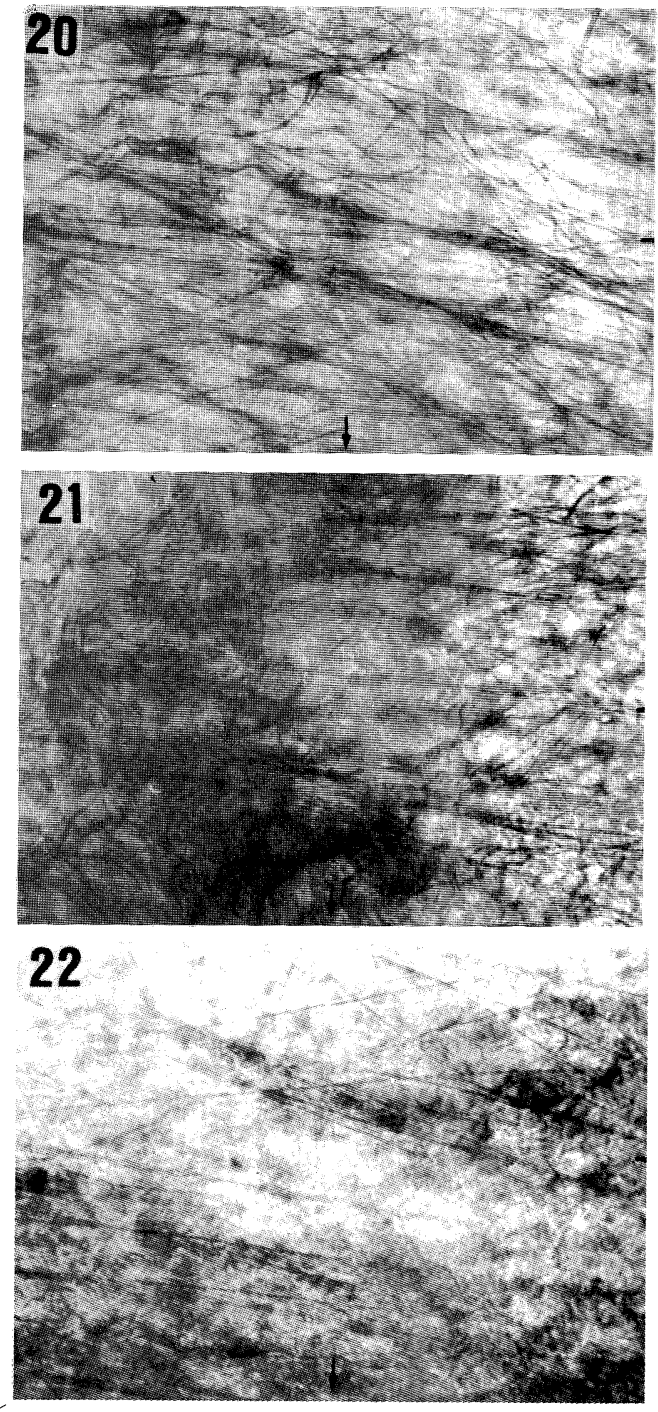

図20.20’関節円板の anterior extension の滑膜.

図21,21'関節円板の bilaminar zone の superior stratum の滑膜。

図22.22'関節円板の anterior mandibular attachment $の$ 滑膜.

図23. 23' 関節円板の内側の外側翼突筋停止部周辺の滑膜.

図24.24'関節円板の medial temporal attachment の滑膜.

図25.25，関節円板周辺部の内側の後方部の滑膜.

図26.26, 関節円板中心部の滑膜.

図27.27, 関節円板周辺部の外側の滑膜.

図28.28' 関節円板の lateral temporal attachment の滑 膜.

図29図20.20’ 28.28’の部位.
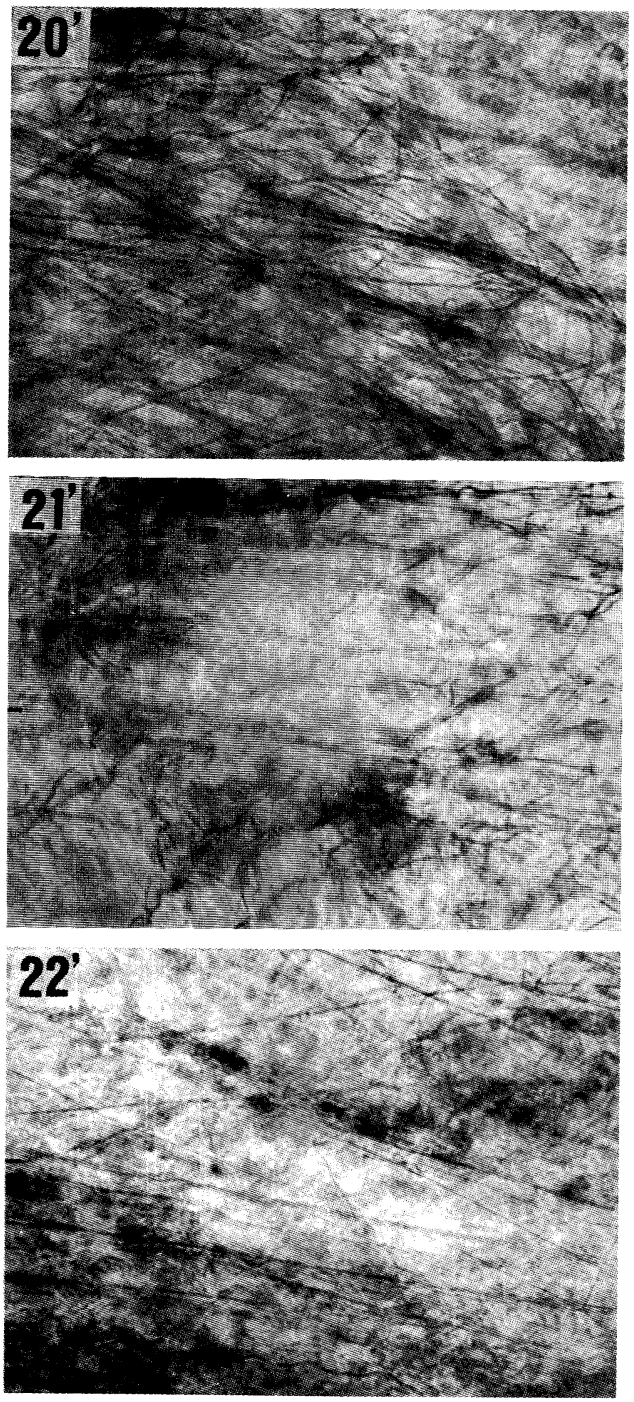

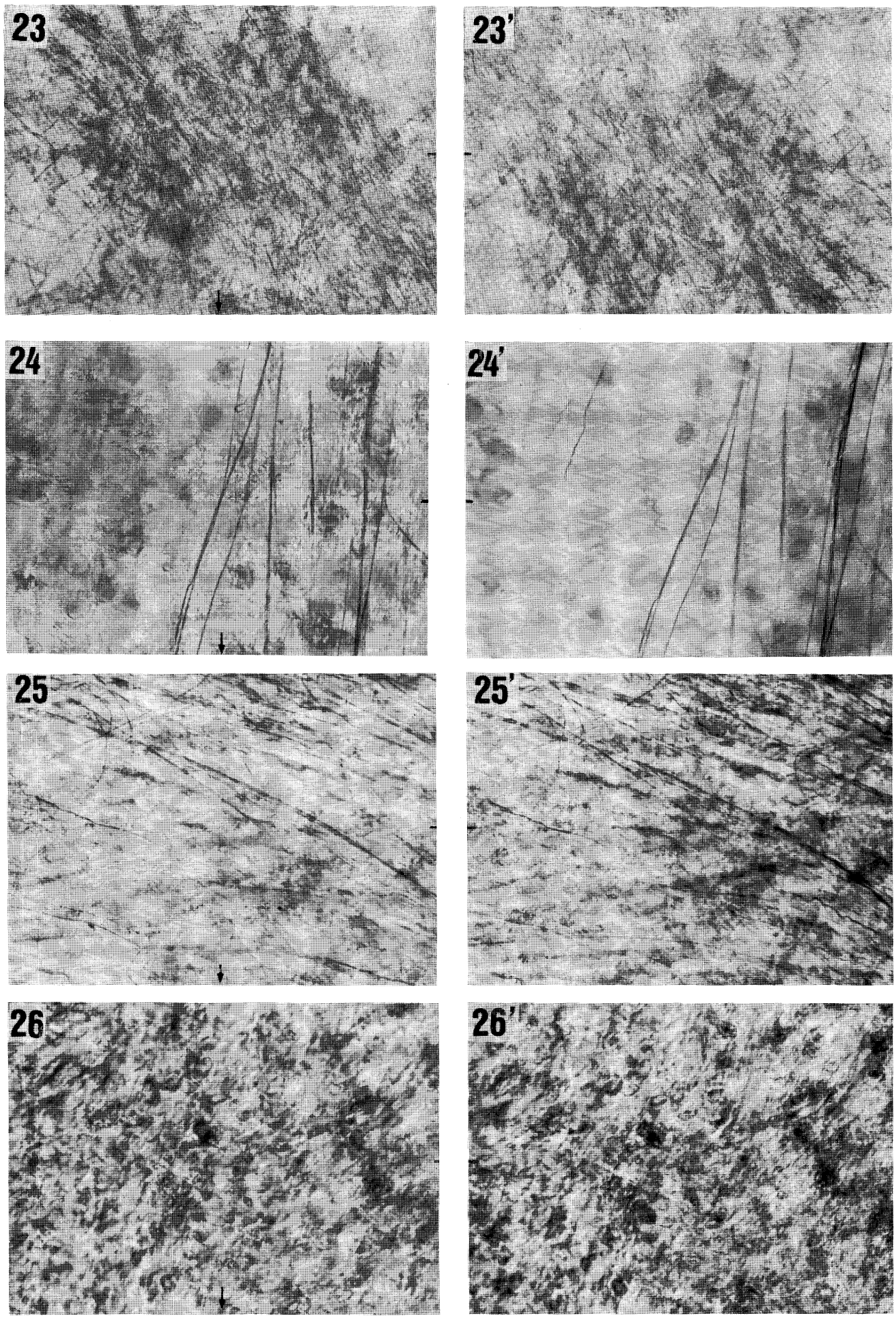

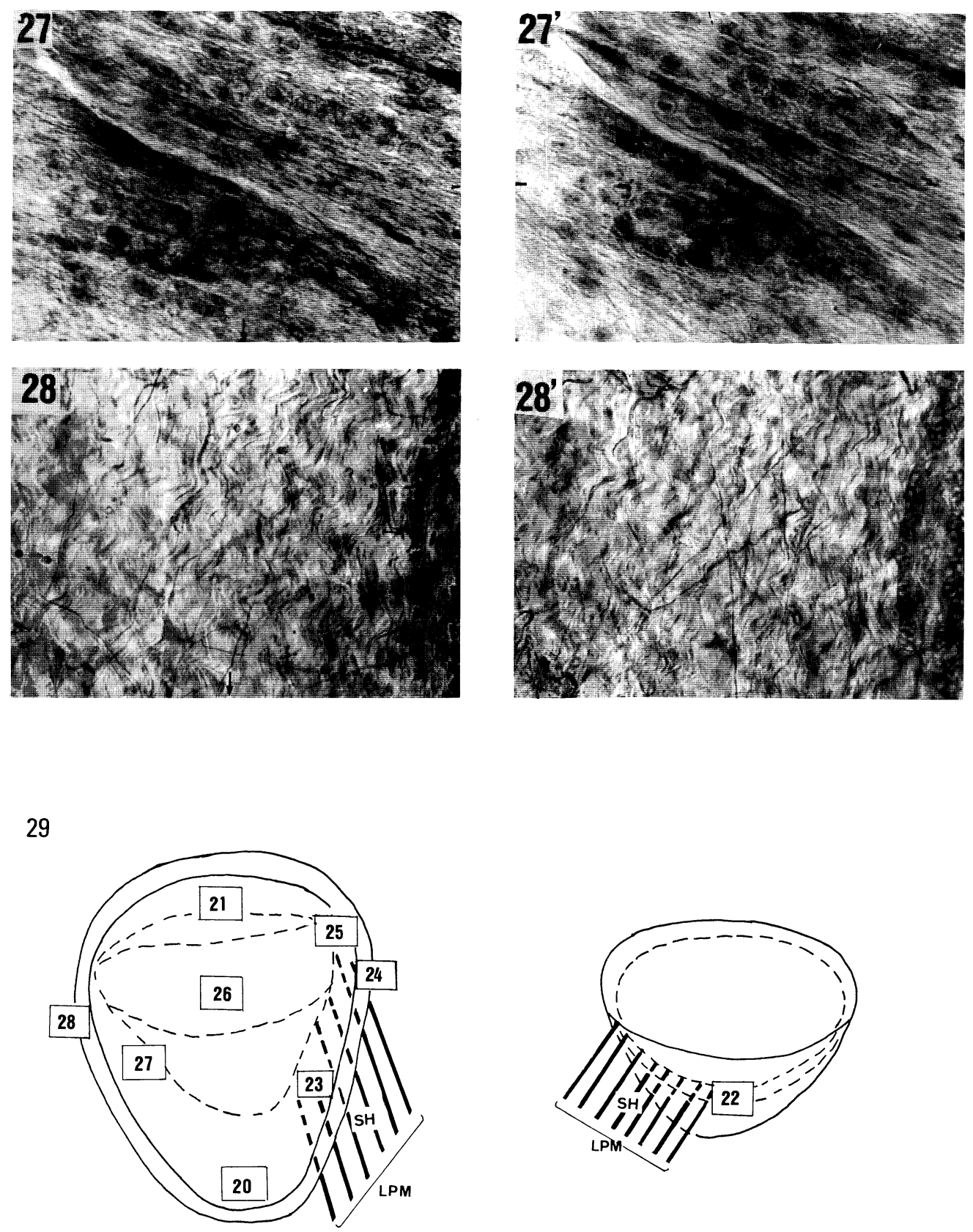


\section{文献}

1) Baecker, R.: Zur Histologie des Kiefergelenkmeniskus des Menschen und der Säuger, Z. mikr.-Anat. Forsch., 26:223-268, 1931.

2) Bentenrieder, A.: Zur Kenntnis des Bindegewebsgerüstes der menschlichen Darmwand, insbesondere über Serosa, Gefä $\beta$ beziehungen und kerkringsche Falten, Z. f. A., Bd, $109: 513$ -543, 1939.

3) Brasch, J.C.: Cunningham's textbook of anatomy, 9th ed, Oxford Univ. Press, 1952, pp. 350-351.

4) Braus, H. : Anatomie des Menschen, Iste Band, 3Auflage, Springer-Verlag., 1954, pp. 702-719.

5) Benninghoff, A. : Lehrbuch der Anatomie des Menschen, Erster Band. J. F. Lehmannsverlag, Münhen-Berlin, 1961, pp. 484-493.

6) Barland, P., Novikoff, A.B. \& Hamerman, D. : Electoron microscopy of the human synovial membrane, J. Cell Biology, 14 : 207-220, 1962.

7) Breathnach, A.S. : Frazer's anatomy of human skeleton, 6th ed., Churchill Co., London, 1965, pp. 190-235.

8) Basmajian, J.V.: Muscles alive, 3rd ed, Williams \& Wilkins Co., Baltiomore, 1974, pp. 399-419.

9) Bloom, W. and Fawcett, D.W. : A textbook of histology, 10th ed, W. B. Sauders Co., Philaderphia, 1975, pp. 282-285.

10) Carlsöö, S. : Nervous coordination and mechanical function of the mandibular elevators : an electromyographic study of the activity and an anatomic analysis of the machanics of the muscles, Acta Odont. Scandinav., 10 suppl. 11:1-132. 1952.

11) Castor, C.W. : The microscopic structure of normal human synovial tissue, Arth. and Rheumat., 3:140-151, 1960.

12) Carlson, D.S., McNamara, J.A.Jr. and Jaul D.J. : Histological analysis of the growth of the mandibular condyle in rhesus monkey (Macaca mulatta), Am. J. Anat., 151 : 103-118, 1978.
13) Davies, D.V.: Anatomy and physiology of diarthrodial joints, Ann. Rheum. Vis., 5, 29 : 29-35, 1945.

14) Dixon, A.D.: The human temporomandibular joint disc, J. Anat. (Lond), 93 : 568, 1959.

15) Dixon, A.D. : Structure and functional significance of the intraarticular disc of the human temporomandibular joint, O.S. O.M. and O.P., 15: 48-61, 1962.

16) Fick, R. : Anatomie der Gelenk. im Handbuch der Anatomie und Mechanik der Gelenk, Erste Bde., Verlag von Gustav Fischer, Jena, 1904, pp. 48-56.

17) Frommer, J. and Monroe, C.W. : Development and distribution of elastic fibers in the mandibular joint of the mouse, Anat. Rec., 156 :333-346, 1956.

18) Findlay, I.A. : Mandibular joint pressures, J. Dent. Res., 43(1) : 140-148, 1963.

19）布施修一郎： ラット顎関節円板の線維構築の 機能的意義に関する走査ならびに透過電顕学的 研究, 口病誌., 47(1)：9-21, 1980.

20) Gegenbaur, C. : Lehrbuch der Anatomie des Menschen, lster Band, 7Auflage, Verlag von Wilhelm-Engelmann, 1895, pp. 240-242.

21) Griffin, C.J. and Sharpe, C.J. : The structur of the adult human temporomandibular meniscus, Aust. Dent. J., 5：190-195, 1960.

22) Gardner, E., Gray, J. and O'Rahilly, R. : Head and neck, in anatomy, Saunders Co., Philadelphia, 1960, pp. 830-835.

23) Griffin, C.J., and Sharpe, C.J. : Distribution of elastic tissue in the human temporomandibular meniscus especially in respect to "compression" areas, Aust. Dent. J., 7 : 72-78, 1962.

24) Grant, P.G. : Lateral pterygoid : two muscles ?, Am. J. Anat., 138:1-10, 1973- A .

25) Grant, P.G. : Biomechanical significance of the instantaneous center of rotation: the human temporomandibular joint, J. Biomechanics, $6: 109-113,1973-\mathrm{B}$.

26) Hammer, A. : Über den feineren Bau der Gelenke, Archiv, f. mikro. Anat., 43 : 266-326, 813-885, 1882. 
27) Ham, A.W. : Joints, in histology, 6th ed., J. B. Lippincott Co., Philadelphia, 1969, pp. 461 $-476$.

28) Key, J.A.: The synovial membrance of joints and bursae, in Cowdry's special cytology, 2nd ed., Hoeber, New York, 1932, pp. 1053 -1085 .

29）黑江 健： 顎関節に関する機能解剖学的研 究, 鹿児島医誌, 32：833-892, 1956.

30）上条雍彦：口腔解剖学. 2 , 筋学, 2 版, ア十 卜一么社, 東京, 1969, pp. 付 1 ～付76.

31) Klineberg, I.J. Greenfield, B.E. and Wyke B. D. : Contributions to the reflex control of mastication from mechanoreceptors in the tempormandibular joint capsule, Dent. Practit., 21(3) : 73-84, 1970.

32) Lubosch, W. : Unter den Meniscus im Kiefergelenk des Menschen, Anat. Anz., 29: 417 $-431,1906$.

33) Lubosch, W. : Über Variation am Tuberculum articulare des Kiefergelenks des Menschen und ihre morphologische Bedeutung, Gegenbaurs Morph. Jahrbuch, 35:322-353, 1906.

34) Moyers, R.E. : An electromyographic analysis of certain muscles involved in temporomandibular movement, American J. Orth., (7) : 481-515, 1950.

35) MacConaill, M.A. : The geometry and algebra of articular Kinematics, Biomedical Engineering, april : 205-211, 1966.

36) MacConaill, M.A. : A structuro-functional classification of synovial articular units, Zr. J. Med. Sc., 142 : 19-26, 1973.

37) McNamara, J.A.Jr. : The independent function of the two heads of the lateral pterygoid muscle, Am. J. Anat., 138 : 197-206, 1973.

38) Norgaard, F.: Arthrography of the mandibular joint, Acta Radiologica, 25 : 679-685, 1944.

39) Nomina histologica Leningrad, Moscow, 1972, p. 42.

40) Nomina histologica Tokyo, Tokyo, 1975, p. 14.
41) Nomina histologica, 4th ed., Excepta medica, Amsterdam, 1977, p. H14.

42) Petersen, H. : Die Organe des Skeletsytems, In Möllendorff, Handbuch der mikroskopischen Anatomie des Menschen, 7 Bde., Teil 2, Julius Springer, Berlin, 1930, pp. 648-677.

43) Pfeiffer, L.: Uber den feineren Bau der Taenia fibrosa Ilei, Anat. Anz. Bd., 86:177 $-195,1938$.

44) Rees, L.A. : The structure and function of mandibular joint, Brit. D. J., 96:125-133, 1954.

45) Rickett, R.M. : Roentgenography of the temporomandibular joint, in the temporomandibular joint, 2nd. ed., Charles C Thomas Publisher, Springfield, 1964, pp. 102-132.

46) Schaffer, J. : Die Stützgewebe, In Möllendorff, Handbuch der mikroskopischen Anatomie des Menschen, 7 Bed., Teil 2, Julius Springer, Berlin, 1930, pp. 368-375.

47) Shapiro, H.H. : Maxillofacial anatomy with practical application, J. B. Lippincott Co., Philaderphia, 1954, pp. 259-287.

48) Sarnat, B.G. : The temporomandibular joint, 2nd ed., Charles C Thomas Publisher, Springfield, 1964.

49) Sicher, H. : Orban's Oral histology and embryology, 6th ed., C. V. Mosby Co., Saint Louis, 1966, pp. 335-343.

50）鈴木 禎： 各種動物の顎関節円板にみられる 軟骨細胞の分布並びに機能的意義について, 歯 科学報, 71(5)：1301-1355，1971.

51）神宮司洋一, 滝沢安子吉, 井原邦夫：ヒトの 胸鎖関節及び顎関節における関節円板につい て，解剖誌，55(4)：341-342，1980.

52）滝沢安子吉： 結腸に於ける taniae fibrosaeに ついて(腹膜の線維構築について第 1 報), 解剖 誌, 24(2) : 55-59, 1949.

53）滝沢安子吉： 膀胱に関係する腹膜の機能的構 造, 腹膜の線維構築について(2), 日新医学, 37 (2) : 25-31, 1950.

54) Thilander, B. : The structure of the collagen of the temporomandibular disc in man, Acta Odont. Scand., 22 : 135-149, 1964. 
55）高久 暹： Personal communication, 1980.

56) Vogt, W. : Eine Tänia fibrosa als Längsverspannung am menschlichen Dünndarm, Verh. anat. Ges., 43. Vers, Jena : 274-282, 1935.

57) Warwick, R. and Williams, P.L. : Gray's antomy, 35th ed., Longman, London, 1973, pp. 401-411.

58) Zenker, W. : Über einige neue Befunde am M. temporalis des Menschen, Z. Anat. Bd., 118
:355-368, 1955.

59) Zenker, W. und Zenker, A. : Die Tätigkeit der Kiefermuskeln und ihre elektromyographische Analyse, Z. Anat. Bd., 119: 174-200, 1955.

60) Zenker, W. : Das retroarticuläre plastische Polster des Kiefergelenkes und seine mechanische Bedeutung, Z. Anat. Bd., 119 : 375-388, 1956. 


\title{
FIBRO-ARCHITECTONICS OF HUMAN TEMPOROMANDIBULAR JOINT
}

\author{
KUNIO IHARA \\ Second Department of Anatomy \\ School of Medicine, Gunma University, \\ Maebashi, Japan \\ (Director : Prof. Akoyoshi Takisawa)
}

To observe the fiber architectonics of the human temporomandibular joint, i. e. that of its discus interarticularis as well as of its synovial membrane, the author carried out the following three methods. 1. The joint has been sectioned in toto with tungsten knife, by the use of Reichert-Jung Heavy-duty Mikrotome type K, after embedded in histosec and followed routine procedures. 2. The small part of the joint containing joint-space lining tissues are embedded in styrene and sectioned with glass knife. 3 . The synovial membrane was stripped off under binocular microscope (10-30X) after bathed in staining fluids (membrane-like film preparation). The fiber-architectures are described of the synovial membrane and the disc. The synovial membrane consists typically of synovial cells ( $\mathbf{s}$ in the figures), lamina propria (ps) and subsynovial tissue (ts). In the central part of the disc, where the fibro-cartilage cells are observed, the fibers of ps-layer and ts-layer and of the disc unit. In the peripheral region and the transitional parts to articular cartilage (attachment-Rees, 1954) the three layers are distinguishable. In film preparation can be obtained views unexpected from the section preparation ; fig. 16 shows the medial peripheral part in section, fig. 17 shows the synovial membrane being observed from the synovial surface in film preparation. The collagen fibers, of the ps-layer, forming bundles, run in concentric circle to the central part of the disc, but the collagen fibers of the ts-layer run radially. Elastic fibers, running in concentric circle to the same part, form three-dimentional net-work.

The fiber-running directions give a hint for the movement of the joint and its disc.

Key words: Articulatio temporomandibularis, Membrana synovialis, Fibro-architectonics, Film-preparation. 